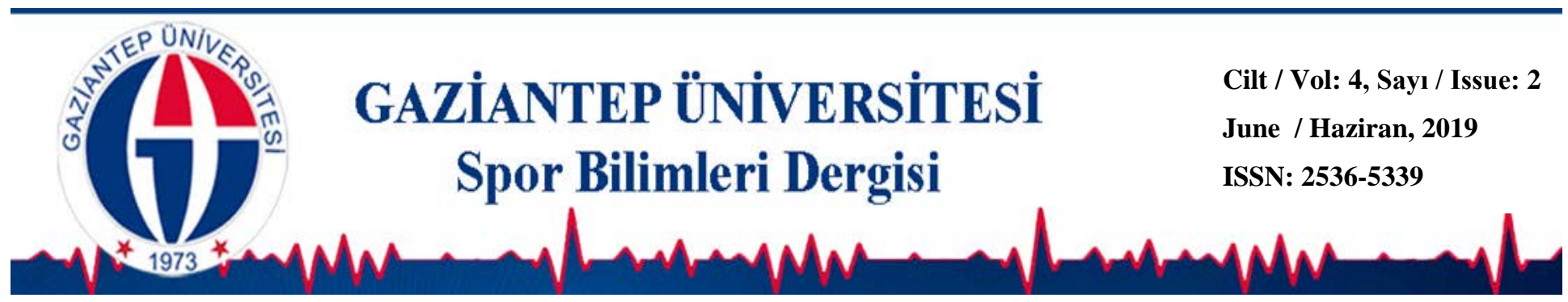

\title{
Ortaöğretim Öğrencilerinin Şiddet Eğilim Durumlarının Belirlenmesi
}

\author{
Tamer KARADEMIR ${ }^{1}$ (D) \\ Ayhan KAYABAŞI $\left.\right|^{2}$ (D) \\ Mehmet VURAL ${ }^{3 *}$ ic \\ ${ }^{1}$ Kahramanmaraş Sütçü İmam Üniversitesi, Beden Eğitimi ve Spor Yüksekokulu, KAHRAMANMARAŞ \\ ${ }^{2}$ Milli Ĕgitim Bakanlığl, Osmangazi Ortaokulu, KAHRAMANMRAŞ \\ ${ }^{3}$ Gaziantep Üniversitesi, Beden Eğitimi ve Spor Yüksekokulu, GAZIANTEP
}

\section{DOI: 10.31680/gaunjss.567010}

Orijinal Makale / Original Article

Geliș Tarihi / Received: 17.05.2019
Kabul Tarihi / Accepted: 30.05.2019

\section{Öz}

$\mathrm{Bu}$ araştırmanın amacı ortaöğretimde eğitim gören öğrencilerin şiddet eğilim durumlarının belirlenmesidir. Bu amaç doğrultusunda 145 kız, 244 erkek öğrenci olmak üzere toplamda 389 öğrenci çalışmaya gönüllü olarak katılmıştır. Katılımcılara 20 sorudan oluşan şiddet eğilim ölçeği uygulanmıştır. Bireylerin şiddet eğilim ortalamaları cinsiyet, yaş, sınıf, alan, spor geçmişi, aile geliri gibi çeşitli değişkenler açısından incelenmiştir. Araştırmadan elde edilen verilerin analizinde SPSS 20.0 programı kullanılmıştır. Verilere normallik testi (Kolmogorow-Smirnov D test) ve veri sayısına bakılarak uygun olan test yöntemleri belirlenmiştir. Araştırmanın verileri parametrik test uygulayacak kadar normal dağılım göstermediğinden Kruskal-Wallis $H$, Mann-Whitney $U$ testlerinden yararlanılmıştır. İstatistikî analizlerde anlamlılık düzeyi $p<0.05$ olarak seçilmiştir. Yapılan analizler sonucunda katılımcıların cinsiyet, eğitim alanı, spor geçmişi, aile geliri, anne-baba eğitim durumu, okul türü (düz ve spor lisesi), anne-baba çalışma durumu, kardeş sayısı ve anne-baba tutumu değişkenlerinde istatistiksel olarak anlamlı bir farklılık tespit edilememiştir $(p>0,05)$. Araştırma grubunun kendini tanımla ve arkadaşını tanımla değişkeninde istatistiksel olarak anlamlı farklılık ortaya çıkmıştır $(p<0,05)$. Sonuç olarak ortaöğretim seviyesinde eğitim gören bireylerin şiddet eğilimleri arkadaş grubunun sahip olduğu özelliklerden ve kendisinin sahip olduğu durumdan etkilendiği söylenebilir.

Anahtar kelimeler: Şiddet, ortaöğretim, eğilim

\section{Determination Violence Tendency Situation of the Secondary Education Students}

\section{Abstract}

The aim of this study was to determine the tendency of violence in secondary education students. For this purpose, a total of 389 (145 female), (244 male) students voluntarily participated in the study. The participants were given a 20 -item violence tendency scale. The averages of violence tendency of individuals were examined in terms of various variables such as gender, age, class, area, sports history, family income. SPSS 20.0 program was used to analyze the data obtained from the study. The appropriate test methods for the study purpose was determined using the number of data and the normality test (Kolmogorow-Smirnov $\mathrm{D}$ test). Kruskal-Wallis $\mathrm{H}$, Mann-Whitney $U$ tests were used because the data of the study did not show normal curve. The significance level was determined as $p<0.05$. As a result of the analyzes significance differences was no found in terms of gender, education area, sports background, family income, parental education status, school type (normal high school and sports high school), parental status, number of siblings and parental attitudes $(p<0,05)$. A statistically significant difference was found in the define yourself and define friend variable in the study $(p<0.05)$. As a result, it could be said that violence tendency of the individuals who educated at normal high school and sports high school is affected by their situation and their friend group.

Key words: Violence, secondary education, tendency

\footnotetext{
* Sorumlu Yazar: Mehmet VURAL
}

E-mail: mehmetvrl27@hotmail.com 


\section{Giriş}

Şiddet bir kişiye kendi hür iradesi dışında bir takım davranışları uygulamak veya uygulaması için zor kullanmaktır. Diğer bir boyutla şiddet; kişinin sahip olduğu fiziki veya psikolojik duruma karşı oluşturulmuş bir zorlama olarak da tanımlanabilir. Bir toplumda yaşan bireylerin birbirlerine karşı veya toplumun içinde oluşmuş kurallar, töreler veya ahlaki değerlere karşı doğrudan veya dolaylı olarak zarar verici davranışların olması o ortamda şiddetin olduğunun göstergesi olmuştur (Kaptanoğlu, 2002).

Çocuklarda ve gençlerde şiddete yönelik davranış ve düşüncelerin ortaya çıkmasına etki eden faktörler hem bireyin kendisinden hem de çevresinden kaynaklanabilir. Çevresel faktörlerin başında okul gelmektedir. Dünya genelinde ya da Türkiye' de araştırma sonuçlarına göre meydana gelen şiddet olguları bireyin sahip olduğu genetik özelliklerden dolayı değil de daha çok kültürel ve sosyal çevreden kaynaklanmaktadır (Yavuzer, 2000).

Okullarda öğrenim gören çocuklarda oluşan şiddet eğilimlerinin meydana gelmesinde okulda geçirilen süre içinde karşılaştıkları durumlar etkili olabilmektedir. Öğrencilerin zamanlarının çoğunu okulda geçirdikleri için davranışlarının yönlendirilmesini de okul ortamında yaşamaktadır. Bireyde şiddet eğiliminin seviyesinin belirlenmesindeki en büyük rol aynı okul içerinde bulunan arkadaşları, öğretmenleri ve yöneticileridir kısacası çevresel faktörlerdir. Okul bir öğrencinin üzerinde sosyal, kültürel ve psikolojik açıdan önemli etkiler oluşturmaktadır. Bu etkiler öğrenciyi doğrudan etkileyip sergilemiş olduğu davranışlarına birincil elden yön vermektedir (Akman, 2010). Yapılan araştırmalar da şiddet eğilimi içerin davranışların çevreden öğrenilen veya doğumdan sonra oluşmuş davranışlar olduğunu ortaya koymuşlardır (Bandura, 1977; Meyer ve Farrell, 1998).

Öğrencilerin şiddet eğilimleri üzerine yapılan çalışmalarda şiddet eğilim seviyesinin yüksek olduğunu ifade eden çalışmalar bulunmaktadır (Öğülmüş, 1995; Pişkin, 2003; Karaman-Kepenekçi ve Çınkır, 2003; Durmuş ve Gürgan, 2005; Yavuzer ve ark., 2009). Daha önce yapılan bir çalışmada ortaöğretim seviyesinde eğim gören bireylerin son zamanlarda \% 116.1' lik bir bölümünün şiddetle karşı karşıya kaldığını, \%8.8'inin doğrudan kedisinin şiddet uyguladığı, \%20.6'sının da hem şiddet uyguladığı hem de şiddet gördüğünü ortaya koymuşlardır., bunlara ek olarak genel olarak öğrencilerin şiddetle ilgili bir durumla yüz yüze gelme oranlarının 
da \%45.5 olduğunu açıklamışlardır (Özcebe ve ark., 2006). Öğrencilerinin şiddete yönelik eğilimlerinin incelendiği başka bir çalışmada, öğrencilerin son zamanlarda \%42'sinin şiddetle alakalı bir kavga olayına dahil oldukları görülmüştür (Alikasifoğlu ve ark., 2004).

Toplum içinde uyumlu ve psikolojik açıdan sağlıklı bir birey olabilmek için o toplumda bulunan aileler ve eğitim kurumlarındaki ilişkiler önem arz etmektedir. Bu düşünceden hareketle şiddetin bireylerin yaşam kalitesini ve başarısını olumsuz yönde etkilediği göz önüne alınarak bireyde şiddet eğilimini ortaya çıkarabilecek unsurların en aza indirilmesi veya ortadan kaldırılmasına yönelik okul ve aile ortamlarında yapılan etkinlikler ve uygulamalar dikkate alınmalıdır. Yukarıda bahsedilen araştırmalarda şiddetin ortaya çıkması çeşitli sebeplere bağlanabilmektedir. Bunlar ailevi, okul ortamı veya ekonomik olarak ortaya çıkabilmektedir. Bundan dolayı özellikle eğitim sürecinde bireylerin şiddet durumlarının ve buna neden olabilecek unsurların belirlenmesi bu konuda önemli bir yer tutmaktadır. Yukarıdaki bilgiler ışığında çalışmamızın amacı; ortaöğretim öğrencilerinin şiddet eğilim durumlarının belirlenmesidir.

\section{Yöntem}

Araştırmamı betimleyici tarama modeli ile oluşturulmuştur. Ayrıca araştırmada ortaokul öğrencilerinin şiddet eğilimlerini cinsiyete, kardeş sayısına, aile yapısına, ekonomik duruma ve anne-baba tutumuna göre farklılaşıp farklılaşmadığını öğrenmek amacıyla nedensel karşılaştırma modelini de içermektedir.

Araştırmamızın evrenini Gaziantep ve Kahramanmaraş ilinde spor lisesi ve Anadolu lisesinde okuyan öğrenciler oluşturmaktadır. Çalışmamıza 145 kadın ve 244 erkek olmak üzere toplamda 389 kişi katılmıştır.

Şiddet Eğilim Ölçeği (Ş.E.Ö): Bu ölçek Göka ve ark. aracılığıyla 1995 yılında Milli Eğitim Bakanlığı üzerinden uygulamaya konulan "Orta Öğretim Kurumlarında Okuyan Öğrencilerin Saldırganlık ve şiddet Eğilimleri” içerikli incelemede değerli veriler elde edebilmek maksadıyla oluşturulmuştur. Aile Araştırma Kurumu'nun "Aile İçinde ve Toplumsal Alanda Şiddet" içerikli çalışmasında 7-14 yaş aralığında olan bireylerin şiddete yönelik meyillerini araştırmak amacıyla tekrardan tasarlanarak meydana getirilmiştir. Bizim çalışmamızda ortaöğretim öğrencilerinin şiddet durumlarını belirlemek için kullanılan ölçekte toplamda 20 ifade bulunmaktadır ve bu 
ölçek dörtlü likert düzeneğinde hazırlanmıştır. Ölçek değerlendirmesinde ifadeler 4 ile 1 aralığında oluşmuş olup çok uygundan hiç uygun değil tarzında oluşturulmuştur. Ölçekte yer alan tüm ifadeler tek yönlüdür. Ölçekten elde edilen ortalamaların yüksek olması öğrencilerin daha yüksek eğilimine sahip olduklarını göstermiştir. Düşük olması ise düşük şiddet eğilimlerine sahip olduklarını göstermektedir. Çalışmada kullanılan ölçme aracı için Cronbach alpha değeri 0.76 olarak hesaplanmıştır.

Araştırmadan elde edilen verilerin analizinde SPSS 20.0 programı kullanılmıştır. Verilere normallik testi (Kolmogorow-Smirnov testi) ve veri sayısına bakılarak uygun olan test yöntemleri belirlenmiştir. Araştırmanın verileri parametrik test uygulayacak kadar normal dağılım göstermediğinden Kruskal-Wallis $H$, MannWhitney $U$ testlerinden yararlanılmıştır. İstatistikî analizlerde anlamlılık düzeyi $p<0.05$ olarak seçilmiştir.

\section{Bulgular}

Tablo 1. Araştırma Grubunun çeşitli kişisel özellikleri ile ilgili t testi sonuçları

\begin{tabular}{|c|c|c|c|c|c|c|}
\hline Değişkenler & Gruplar & $\mathbf{n}$ & Ort. & SS. & $t$ & $p$ \\
\hline \multirow{2}{*}{ Cinsiyet } & $\mathrm{K} ı \mathrm{Z}$ & 145 & 2,34 & 0,49 & \multirow{2}{*}{$-1,038$} & \multirow{2}{*}{0,299} \\
\hline & Erkek & 244 & 2,28 & 0,48 & & \\
\hline \multirow{2}{*}{ Okul Türü } & Spor Lisesi & 184 & 2,24 & 0,45 & \multirow{2}{*}{$-2,061$} & \multirow{2}{*}{0,039 * } \\
\hline & Düz Lise & 205 & 2,35 & 0,51 & & \\
\hline \multirow{2}{*}{ Anne Çalışıyor mu? } & Evet & 87 & 2,29 & 0,53 & \multirow{2}{*}{$-0,103$} & \multirow{2}{*}{0,918} \\
\hline & Hayır & 302 & 2,3 & 0,47 & & \\
\hline \multirow{2}{*}{ Baba Çalışıyor mu? } & Evet & 322 & 2,31 & 0,49 & \multirow{2}{*}{$-0,728$} & \multirow{2}{*}{0,467} \\
\hline & Hayır & 66 & 2,26 & 0,45 & & \\
\hline \multirow{2}{*}{ Anne Baba Birlikte mi? } & Evet & 349 & 2,3 & 0,48 & \multirow{2}{*}{$-0,192$} & \multirow{2}{*}{0,848} \\
\hline & Hayır & 39 & 2,31 & 0,5 & & \\
\hline \multirow{2}{*}{ Kendini Tanımla } & İçe Kapanık & 141 & 2,23 & 0,46 & \multirow{2}{*}{$-2,443$} & \multirow{2}{*}{$0,015^{*}$} \\
\hline & Dışa Dönük & 248 & 2,34 & 0,49 & & \\
\hline
\end{tabular}

Tablo 1'e göre araştırma grubunun şiddet eğilim ölçeği puan ortalamaları cinsiyet, anne baba çalışma ve birlikteliği değişkenleri açısından herhangi bir farklılık görülmezken ( $p>0.05)$, okul türü ve kendini tanımla değişkenleri açısından anlamlı farklılıklara rastlanmıştır $(p<0.05)$. Diğer bir değişle okul türü spor lisesi olan öğrencilerin şiddet eğilimi puanlarının düz lise öğrencilerinden daha düşük olduğu tespit edilmiştir. Ayrıca kendini dışa dönük biri olarak tanımlayan öğrencilerin şiddet eğilimlerinin daha yüksek olduğu tespit edilmiştir. 
Tablo 2. Araştırma Grubunun çeşitli kişisel özellikleri ile ilgili $X^{2}$ testi sonuçları

\begin{tabular}{|c|c|c|c|c|c|c|c|}
\hline Değişkenler & Gruplar & $\mathbf{n}$ & Ort. & SS. & $x^{2}$ & $\mathbf{p}$ & $\begin{array}{c}\text { Fark U } \\
\text { Testi }\end{array}$ \\
\hline \multirow{4}{*}{ Sınıf } & 1.sinıf & 94 & 2,17 & 0,46 & \multirow{4}{*}{8,334} & \multirow{4}{*}{0,4} & \\
\hline & $2 . \sin I f$ & 225 & 2,34 & 0,46 & & & \\
\hline & $3 . \sin I f$ & 41 & 2,38 & 0,54 & & & \\
\hline & $4 . \sin I f$ & 29 & 2,31 & 0,56 & & & \\
\hline \multirow{4}{*}{ Alanı } & Sözel & 32 & 2,38 & 0,41 & \multirow{4}{*}{4,735} & \multirow{4}{*}{0,192} & \\
\hline & Eşit Ağırlık & 86 & 2,35 & 0,56 & & & \\
\hline & Sayısal & 112 & 2,33 & 0,47 & & & \\
\hline & Spor bölümü & 159 & 2,24 & 0,45 & & & \\
\hline \multirow{3}{*}{ Spor Geçmişi } & $1-3$ yıl & 101 & 2,31 & 0,46 & \multirow{3}{*}{2,26} & \multirow{3}{*}{0,323} & \\
\hline & $4-6 \mathrm{yll}$ & 110 & 2,27 & 0,47 & & & \\
\hline & 7 yıl ve üzeri & 35 & 2,2 & 0,08 & & & \\
\hline \multirow{4}{*}{ Aile Geliri } & $1000-2000$ & 111 & 2,32 & 0,48 & \multirow{4}{*}{5,739} & \multirow{4}{*}{0,125} & \\
\hline & $2001-3000$ & 148 & 2,28 & 0,48 & & & \\
\hline & $3001-4000$ & 79 & 2,23 & 0,51 & & & \\
\hline & 4000 üzeri & 51 & 2,43 & 0,44 & & & \\
\hline \multirow{4}{*}{$\begin{array}{l}\text { Anne Eğitim } \\
\text { Durumu }\end{array}$} & İlköğretim & 178 & 2,26 & 0,45 & \multirow{4}{*}{5,646} & \multirow{4}{*}{0,13} & \\
\hline & Ortaöğretim & 110 & 2,31 & 0,51 & & & \\
\hline & Lise & 77 & 2,31 & 0,48 & & & \\
\hline & Üniversite & 24 & 2,56 & 0,57 & & & \\
\hline \multirow{4}{*}{$\begin{array}{l}\text { Baba Eğitim } \\
\text { Durumu }\end{array}$} & İlköğretim & 129 & 2,28 & 0,46 & \multirow{4}{*}{4,482} & \multirow{4}{*}{0,214} & \\
\hline & Ortaöğretim & 119 & 2,25 & 0,48 & & & \\
\hline & Lise & 94 & 2,35 & 0,5 & & & \\
\hline & Üniversite & 47 & 2,39 & 0,51 & & & \\
\hline \multirow{3}{*}{ Kardeş Sayısı } & $1-3$ & 209 & 2,3 & 0,52 & \multirow{3}{*}{0,341} & \multirow{3}{*}{0,843} & \\
\hline & $4-6$ & 156 & 2,32 & 0,46 & & & \\
\hline & 7 ve üzeri & 24 & 2,26 & 0,32 & & & \\
\hline \multirow{4}{*}{ Anne Tutumu } & Demokratik & 138 & 2,24 & 0,41 & \multirow{4}{*}{5,207} & \multirow{4}{*}{0,157} & \\
\hline & Otoriter & 78 & 2,36 & 0,57 & & & \\
\hline & Koruyucu & 158 & 2,3 & 0,48 & & & \\
\hline & İlgisiz & 15 & 2,55 & 0,54 & & & \\
\hline \multirow{4}{*}{ Baba Tutumu } & Demokratik & 150 & 2,24 & 0,47 & & & \\
\hline & Otoriter & 99 & 2,35 & 0,47 & & & \\
\hline & Koruyucu & 115 & 2,3 & 0,49 & 7,125 & 0,068 & \\
\hline & İlgisiz & 25 & 2,46 & 0,55 & & & \\
\hline & 1) Kavgacı & 80 & 2,51 & 0,55 & & & \\
\hline & 2) Sessiz sakin & 66 & 2,29 & 0,54 & & & $\begin{array}{c}1>2,3,4,5 \\
4>3\end{array}$ \\
\hline Arkadaşını & 3) Çalışkan & 75 & 2,15 & 0,44 & 20,526 & $0,00^{*}$ & \\
\hline Ianımla & 4) Umursamaz & 73 & 2,3 & 0,47 & & & \\
\hline & 5) Diğer & 95 & 2,26 & 0,35 & & & \\
\hline
\end{tabular}

Tablo 2'ye göre araştırma grubunun şiddet eğilim ölçeği puan ortalamalarının sınıf, alan, spor geçmişi, aile gelir, anne-baba eğitim, kardeş sayısı ve anne- baba tutumları açısından herhangi bir şekilde farklılaşmadığı görülmüş ( $p>0.05)$, arkadaşını tanımla görüşü açısından anlamlı farklııı̆a rastlanmıştır $(p<0.05)$. Farklılı̆ın hangi gruplar arasında olduğunu belirlemek için yapılan Mann Whitney U testi sonuçlarına göre, arkadaşını kavgacı olarak tanımlayanların şiddet eğilim 
puanlarının diğerlerinden daha yüksek olduğu, umursamaz olanların ise çalışkan olanlardan daha yüksek olduğu tespit edilmiştir.

\section{Tartışma ve Sonuç}

$\mathrm{Bu}$ araştırmada ortaöğretimde eğitim gören öğrencilerin şiddet eğilim durumlarının belirlenmesi amaçlanmıştır. Bu amaç doğrultusunda 145 kız, 244 erkek öğrenci olmak üzere toplamda 389 öğrenci çalışmaya gönüllü olarak katılmıştır. Katılımcılara 20 sorudan oluşan şiddet eğilim ölçeği uygulanmıştır. Çalışmamızda iki majör buğu elde edilmiştir. Bunlardan birincisi katılımcıların şiddet eğilimlerine etki eden arkadaş grubunun özellikleri, ikincisi ise bireyin sahip olduğu psikolojik durumdur. Bireylerin şiddet eğilim ortalamaları cinsiyet, yaş, sınıf, alan, spor geçmişi, aile geliri gibi çeşitli değişkenler açısından incelenmiştir. Araştırmanın sonunda katılımcıların cinsiyet, eğitim alanı, spor geçmişi, aile geliri, anne-baba eğitim durumu, anne-baba çalışma durumu, kardeş sayısı ve anne-baba tutumu değişkenlerinde istatistiksel olarak anlamlı bir farklılık tespit edilememiştir. Araştırma grubunun kendini tanımla, okul türü (düz lise-spor lisesi) ve arkadaşını tanımla değişkeninde istatistiksel olarak anlamlı farklılık ortaya çıkmıştır. Sonuç olarak ortaöğretim seviyesinde eğitim gören bireylerin şiddet eğilimleri arkadaş grubunun sahip olduğu özelliklerden, okuduğu okul türünden ve kendisinin sahip olduğu karakter yapısından etkilendiği söylenebilir.

Daha önce yapılan çalışmalarda ortaöğretim ve lise döneminde eğitim gören bireylerin şiddet eğilimlerinin cinsiyete göre istatistiksel olarak anlamlı bir şekilde farklılaştığı ve bu farklılığın erkeklerde kadınlara oranla daha yüksek çıktığı belirlenmiştir (Balkıs ve ark., 2005; Mahlstedt and Welsh 2005; Özcebe, 2007; Avcı, 2010; Erdoğdu, 2010; Özgür ve ark., 2011; Gençoğlu ve ark., 2014; Giles ve Heyman, 2005; Gullone ve Moore, 2000). Bizim sonuçlarımıza göre katılımcıların şiddet eğilimleri cinsiyete göre farklılaşmamıştır. Karataş ve Kaura ve Lohman tarafından yapılan bir çalışmada da şiddet eğilimlerinin cinsiyete göre değişmediği ortaya çıkarılmıştır (Karataş, 2002; Kaura ve Lohman, 2007).

Çalışmamızda katılımcıların spor geçmişlerinin şiddet eğilimleri üzerinde anlamlı bir etki oluşturmadığı saptanmıştır. Yapılan çalışmalarda katılımcıların spor geçmişleri ile şiddet eğilim durumları arasında anlamlı bir farklılık tespit edilememiştir (Kırımoğlu ve ark., 2008; Dervent, 2007). Yine çalışmamızda istatistiksel olarak 
anlamlı bir farklılık bulunamayan başka bir değişken ise katılımcıların anne-baba tutumlarıdır. Literatürde yapılan çalışmalar incelendiğinde çalışmamızla benzer sonuçlar ortaya çıkarmışlardır (Karakaya, 2008; Yeğen, 2008).

Çalışmamızdan elde edilen sonuçlara göre katılımcılarını anne-baba eğitim durumlarının şiddet eğilimleri üzerinde anlamlı bir etki oluşturmadığı tespit edilmiştir. Daha önce yapılan çalışmalar da bu sonucu destekler niteliktedir. Yapılan çalışmalarda anne-baba eğitim düzeylerinin şiddet eğilimlerini etkilemediği ortaya çıkarılmıştır (Ayan, 2007; Karakaya, 2008; Hüsman, 2007; Kula, 2008; Avcı, 2006). Ailenin gelir durumlarına göre şiddet eğilimlerinin incelenmesi sonucunda anlamlı bir farklılık tespit edilememiştir. Daha önce yapılan çalışmalarda da aile gelir düzeylerinin şiddet eğilimlerinin belirlemede anlamlı bir şekilde etkili olmadığı tespit edilmiştir (Demirhan, 2004; Ayan, 2007; Hüsman 2007; Kula, 2008).

Araştırmalarda maddi olarak düşük seviyede olan, lisenin son sınıfında okuyan öğrencilerin ve aile içerisindeki kardeş sayısının az olduğu ailelerde şiddet algısının ve olgusunun yüksek olabileceği ortaya konmuştur (Akman, 2010; Akman, 2013). Bir başka boyut olarak araştırmalarda gelir düzeyi ile şiddet arasındaki ilişkiden söz edilmiştir (Ağlamaz, 2006; Altınay ve Arat, 2008; Kocacık ve Çağlayandereli, 2009; Özgür ve ark., 2011).

Çalışmamızda katılımcıların "arkadaşını nasıl tanımlarsın” sorusuna verilen yanıtlar analiz edildiğinde şiddet eğilimine yönelik istatistiksel olarak anlamlı şekilde farklılaşmıştır. Arkadaş grubunun bireyin sahip olduğu şiddet eğilim düzeyini anlamlı derecede etkilemiştir. Bir çocuğun toplumu öğrenmesinde, sosyal rollere bürünmesinde veya kuralları ve kaideleri öğrenmesinde birincil etken ailedir. Aileden sonra gelecek en önemli etken ise çocuğun akranları ve çevresindeki sosyal gruplardır. Aile dışında çocuk kendisinin böyle akranlarının olduğu ortamda rahat hissedip rahat bir şekilde davranışlarını sergileyebilir. Bundan dolayı aile içinde görüşülmeyen veya çocuk tarafında çekinilen herhangi bir konu arkadaş grubu içerisinde görüşülebilmektedir. Aynı zamanda görüşülen konulara ilişkin fikirler de arkadaşlar arasında benimsenip yeni bir görüş veya düşünce sahibi olunabilmektedir. Tabiki çocuğun sahip olacağı arkadaş çevresinin özellikleri de ailesinin sahip olduğu ekonomik durumlar, sosyal görüş ve tutumla yakından ilgilidir. Bundan dolayı arkadaş çevresi çocuğun sosyal ve psikolojik gelişimini pozitif düzeyde etkilerken bazı çevreler ise şiddete eğilimli olarak etki etmektedir. (Avcı, 2007). Bu bilgiden hareketle 
bireyin sahip olduğu arkadaş grubunun şiddet eğilimleri üzerine etkisinin olduğu söylenebilir.

Çalışmamızda katılımcılara "kendini nasıl tanımlarsın" sorusuna verilen yanıtlar analiz edildiğinde şiddet eğilimine yönelik verilen yanıtların ortalamaları ile istatistiksel açıdan anlamlılık bulunmuştur. Gerçekleştirilen araştırmalarda bireylerin sahip olduğu şiddet eğilimi ve saldırganlık durumlarının ergenlik dönemlerinin özellikleri ile bağdaştığı öne sürülmektedir. Gordon'un yaptığı bir çalışmada ergen bireylerin istediklerini yapma ve kararlarını açıklamada imkan tanınmadıkları ve bu durum karşısında anlaşılmamış hissi oluşması onların değişik tepkilere büründüğünü ortaya koymuştur. Bu durumlar sonrasında gücenme, darılma, istenmeme, baskılama, engelleme ve sinir gibi durumlarında buna bağlı olarak ortaya çıkabileceği bildirilmiştir. Böyle karmaşık ve zor durgu durumlarını toparlamada çektikleri sıkıntılar dışarıdan herhangi bir kışkırtma olayına karşı bu bireyleri daha hassas bir duruma getirmektedir (Çuhadaroğlu-Çetin, 2008). Bununla aynı paralelde içine kapanık ve yalnız hissine sahip olan ergen bireyler kendilerini ve düşünceleri rahat bir şekilde dile getiremediklerini için içlerinde biriken duygu ve düşüncelerin onları şiddete yöneltmesine müsaade etmiş olmaktadırlar (Johnson ve Johnson, 1995). Bu bireyler için okul da veya arkadaş çevresinde önemsenmek, ilgi alaka görüp yalnız olmama hissini yaşamak oldukça önemlidir. Çünkü bu bireylerin düşünce ve hayal dünyasında sahip olduğu arkadaş çevresi içerisinde etkin bir kişi olma, yeterince tanınma ve intiyaç duyulan bir kişiliğe sahip olma düşüncesi oldukça yaygındır ve onlar için çok önemli anlamlar taşımaktadır (Cowie, 2000). Arkadaş çevresi içinde iyi tanınmış ve ilgi alaka görme düzeyi yüksek olan bireylerin daha çok şiddete eğilimli olduğu görülmüştür (Hawley ve Vaughn, 2003). Çalışmamızın sonucunda ise bireylerin sahip olduğu kişilik özelliklerinin şiddet eğilimleri üzerinde anlamlı bir ilişkisi olduğu ortaya çıkmıştır.

Çalışmamızda son olarak şiddet eğilimlerinin incelendiği okul türü karşılaştırmasında da anlamlı bir farklılık ortaya çıkmıştır. Şiddet eğilimi spor lisesi öğrencilerinde daha az çıkmıştır. Düz lise okuyan öğrencilerin şiddet eğilimleri anlamlı bir şekilde yüksek çıkmıştır. Sporun ruh sağlığı üzerine etkisi birçok araştırmacı tarafından incelenmiştir (Byme ve ark., 1993; Salmon, 2000). Sporun insan organizması üzerinde ruhsal, fizyolojik ve fiziksel olarak bir çok katkısı bilinmektedir. MSS de bir takım düzenlemeler oluşturma (Dishman ve ark., 1997), 
hipotalamopituiter-adrenokortikal yolak aktivitesinde azalmaya neden olma (Droste ve ark., 2003) bir takım hormonların salınımım yükselmesini sağlama (Thoren ve ark., 1990) ve fit olma durumunu güçlendirme (Blumenthal ve ark., 1999; McAuley ve ark., 1997) gibi etkiler sıralanabilir. Sporun, özgüvende artış (McAuley ve ark., 1997; Karakaya ve ark., 2005) olumsuz düşüncelerden uzaklaşma (Fennel ve Teasdale, 1984; Morgan, 1985) uykuda düzelme (Vardar ve ark., 2005) ve strese uyum sağlama (Fox, 1999) gibi psiko-sosyal etmenlerden bahsedilmektedir. Bireylerin sahip olduğu sosyo-ekonomik durum, sosyal durum ve sağlık durumlarını çerçeve dışı yaparak yapılan araştırmada spor ile uğraşmanın stres faktörlerini azaltmada ve şiddete eğilim gösterme oranın azalması ile anlamlı bir ilişki olduğunu ortaya koymuşlardır (Steptoe ve Butler, 1996). Bu bilgilerden hareketle spor lisesinde okuyan öğrencilerin şiddet eğilimlerinin daha düşük olması sporla alakalı bir ortamda bulunmaları ve sporla sürekli bir şekilde ilişkilerinin olmasından kaynaklandığı söylenebilir.

Sonuç olarak, ortaöğretim seviyesinde eğitim gören bireylerin sahip olunan arkadaş çevresinin özellikleri ve sahip olunan kişilik yapısının bireylerin şiddete yönelik eğilimlerini etkilediği söylenebilir.

\section{Kaynaklar}

Ağlamaz, T. (2006). Lise öğrencilerinin saldırganlık puanlarının kendini açma davranışı, okul türü, cinsiyet, sınıf düzeyi, anne-baba öğrenin düzeyi ve ailenin aylık gelir düzeyi açısından incelenmesi. Yayımlanmamış Yüksek Lisans Tezi. Samsun: 19 Mayıs Üniversitesi, Sosyal Bilimler Enstitüsü.

Akman, S. (2013). Lise öğrencilerinin şiddete yönelik tutumları ile okula bağlılık duygusu arasındaki ilişkinin incelenmesi. Yayımlanmamış Yüksek Lisans Tezi. Fatih Üniversitesi Sosyal Bilimler Enstitüsü, İstanbul.

Akman, Y. (2010). İlköğretim ikinci kademe öğrencilerinin şiddet ve okul iklimi algıları arasındaki ilişki. Yayımlanmamış Yüksek Lisans Tezi. Gazi Üniversitesi Eğitim Bilimleri Enstitüsü, Ankara.

Alikasifoğlu M, Ercan O, Erginöz E, ve ark. (2004). Violent behavior among Turkish high school students and correlate of physical fighting. European Journal of Public Health, 14: 173. 
Altınay, A.G. ve Arat, Y. (2008). Türkiye'de kadına yönelik şiddet, (2.baskı). İstanbul: Punto Baskı Çözümleri.

Avcı, M. (2007). Tutuklu Çocuklar Üzerine Bir Araştırma: Çocukların Suça Yönelmesinde Etkili Olan Toplumsal Nedenler ve Çözüm Önerileri. Atatürk Üniversitesi, Sosyal Bilimler Enstitüsü. Sosyoloji Anabilim Dalı, Erzurum.

Avcı, R. (2006). Şiddet davranışı gösteren ve göstermeyen ergenlerin ailelerinin aile işlevleri, öfke ve öfke ifade tarzları açısından incelenmesi. Yayımlanmamış yüksek lisans tezi, Çukurova Üniversitesi, Adana.

Avcl, R. ve Güçray, S.S. (2010). Şiddet davranışı gösteren ve göstermeyen ergenlerin ailelerinin aile işlevleri, öfke ve öfke ifade tarzları açısından incelenmesi. Kuram ve Uygulamada Eğitim Bilimleri, 10 (1), 45-76.

Ayan, S. (2007). Aile içinde şiddete uğrayan çocukların saldırganlık eğilimleri. Anadolu Psikiyatri Dergisi, 8, 206-214.

Balkıs, M., Duru, E. ve Buluş, M. (2005). Şiddete Yönelik Tutumların Öz yeterlilik, Medya, Şiddete Yönelik İnanç, Arkadaş Grubu ve Okula Bağlılık Duygusu ile İlişkisi. Ege Eğitim Dergisi, 6(2), 81-97.

Bandura, A. (1997). Social learning theory. Practice Hall- New Jersey: 22-36.

Blumenthal, JA., Babyak, MA., Moore, KA., Craighead, WE., Herman, S., Khatri, P., et al. (1999). Effects of exercise training on older patients with major depression. Arch Intern Med; 159:2349- 2356.

Byrne, A., Byrne, DG. (1993). The effect of exercise on depression, anxiety and other mood states-A review. J Psychosom Res; 37:565-574.

Cowie, H. (2000). Bystanding or standing by: Gender issues in coping with bullying in schools. Aggressive Behavior, 26, 85-97.

Çuhadaroğlu Çetin, F. (2008). Youth and violence. In M.D. Ulusoy (Eds.). Political violence, organized crimes, terrorism and youth (ss. 11-21). Netherlands: IOS Press.

Dervent, F. (2007). Lise öğrencilerinin saldırganlık düzeyleri ve sportif aktivitelere katııımla ilişkisi. Yayımlanmamış yüksek lisans tezi, Gazi Üniversitesi, Ankara.

Dishman, RK., Renner, KJ., Youngstedt, SD., Reigle, TG., Bunnel, BN., Burke, KA., et al. (1997). Activity wheel running reduces escape latency and alters brain monoamine levels after footshock. Brain Res Bull; 42:399-406. 
Durmuş, E. ve Gürgan, U. (2005). Lise Öğrencilerinin Şiddet ve Saldırganlık Eğilimleri. Türk Eğitim Bilimleri Dergisi, 3(3): 253-269.

Erdoğdu, Y.M. (2010). Öğrencilerin Saldırganlık Eğilimlerinin Bazı Değişkenler Açısından İncelenmeleri. International Conference on New Trends in Education and Their Implications, 835-848

Fennell, M., Teasdale, J. (1984). Effect of distraction on thinking and affect in depressed patients. Br J Clin Psychol; 23:65-66.

Fox KR. (1999). The influence of physical activity on mental wellbeing. Public Health Nutr; 2:411- 418.

Gençoğlu, C., Kumcağız, H. ve Ersanlı, K.(2014). Ergenlerin Şiddet Eğilimine Etki Eden Ailevi Faktörler. Turkish Studies - International Periodical For The Languages, Literature and History of Turkish or Turkic, 9(2), 639-652

Giles, J.W., Heyman, G.D. (2005). Preschoolers' use of trait-relevant information to evaluate the appropriateness of an aggressive response. Aggressive Behavior, 31, 498-509.

Gullane, E. ve Moore, S. (2000), Adolescent risk taking and 5 faktor model of personality. Journal of Adolescence, 23 (4), 393-407.

Hawley, P., Vaughn, B. (2003). Aggression and adaptation: The bright side to bad behavior. Introduction to special volume. Merrill-Palmer Quarterly, 49, 239-244

Hüsman, Z. (2007). Lise ikinci sınıf öğrencilerinin şiddet deneyimlerinin nitelik ve nicelik açısından tetkiki. Yayımlanmamış yüksek lisans tezi, Maltepe Üniversitesi, İstanbul.

Johnson, D.W. \& Johnson, R.T. (1995). Reducing school violence through conflict resolution. [Çevrimiçi: http://books.google.com/books], Erişim tarihi: 8 Mayıs 2019.

Kaptanoğlu, C. (2002). Psikodinamik Açıdan Şiddet, Toplum ve Hekim Derg, 17: 6668.

Karakaya, I., Coşkun, A., Ağaoğlu, B. (2005). Yüzücülerin depresyon, benlik saygısı ve kaygı düzeylerinin değerlendirilmesi. Anadolu Psikiyatri Dergisi; 16:40-45.

Karakaya, E. (2008). Endüstri meslek lisesi öğrencilerinin şiddet eğilimlerinin çok yönlü olarak değerlendirilmesi, İstanbul ili Avrupa yakası örneği. Yayımlanmamış yüksek lisans tezi, Yeditepe Üniversitesi, İstanbul. 
Karaman-Kepenekçi, Y. ve Çınkır, Ş. (2003). Öğrenciler arası zorbalık. Kuram ve Uygulamada Eğitim Yönetimi, 34: 236-253.

Karataş, Z.B. (2002). Anne baba saldırganlığı ile lise öğrencilerinin saldırganlığı arasındaki ilişkinin incelenmesi. Yayımlanmamış yüksek lisans tezi, Çukurova Üniversitesi, Adana.

Kaura, S. ve Lohman, B. (2007). Dating Violence Victimization, Relationship Satisfaction, Mental Health Problems, and Acceptability of Violence: A comparison of Men and Women. Journal of Family Violence. 22, 367-381.

Kırımoğlu, H., Parlak, N., Dereceli,Ç. ve Kepoğlu, A. (2008). Lise öğrencilerinin saldırganlık düzeylerinin spor yapıp yapmama durumlarına göre incelemesi (Aydın il örneği). Niğde Üniversitesi Beden Eğitimi ve Spor Bilimleri Dergisi, 2 (2)Erişim:10.05.2019,http://dergi.nigde.edu.tr/index.php/besyodergi/article/vie $\mathrm{w} / 60 / 50$.

Kula, E. (2008). Endüstri meslek lisesi örgencilerinin umutsuzluk düzeyleri ve saldırganlık durumları arasındaki ilişkinin incelenmesi. Yayımlanmamış yüksek lisans tezi, Yeditepe Üniversitesi, İstanbul.

Mahlstedt, D.L. ve Welsh, L.A. (2005). Perceived causes of physical assault in heterosexual dating relationships. Violence Against Women, 11, 447-472.

McAuley, E., Mihalko, SL., Bane, SM. (1997). Exercise and self-esteem in middleaged adults: multidimensional relationships and physical fitness and selfefficacy influences. J Behav Med; 20:67-83.

Meyer AL, Farrell AD (1998). Social skills training to promote resilience in urban sixthgrade students: one product of an action research strategy to prevent youth violence in high-risk environments. Education \& Treatment of Children 21(4): 461-478.

Morgan WP. (1985). Affective beneficence of vigorous physical activity. Med Sci Sports Exerc; 17:94-100

Öğülmüş, S. (1995). Okullarda şiddet ve vandalizm. Yayınlanmamış Araştırma Raporu, Ankara

Özcebe, H. (2007). Gençlerde riskli davranışlar ve sağlığın geliştirilmesi: Türkiye'de gençlerin sağlığına genel bir bakış. XI. Ulusal Halk Sağlığı Kongresi Kitabı, Denizli. 
Özcebe, H., Üner, S. ve Çetik, H. (2006). Adolesanlarda şiddet davranışları. I. Şiddet ve Okul: Okul Ve Çevresinde Çocuğa Yönelik Şiddet ve Alınabilecek Tedbirler Sempozyumu. İstanbul. 28-31 Mart 2006, MEB, ÜNICEF, Erişim Tarihi: 13.05.2019 http://iogm.meb.gov.tr/ siddetveokul/

Özgür, G., Yörükoğlu, G. ve Baysan Arabacı, L. (2011). Lise Öğrencilerinin Şiddet Algıları, Şiddet Eğilim Düzeyleri ve Etkileyen Faktörler. Psikiyatri Hemşireliği Dergisi, 2(2), 53-60.

Salmon P. (2000). Effects of physical exercise on anxiety, depression, and sensitivity to stres: a unifyingtheory. Clin Psychol Rev; 21:33-61.

Steptoe A, Butler N. (1996). Sports participation and emotional wellbeing in adolescents. Lancet; 347:1789-1792.

Thoren P, Floras JS, Hoffmann P, Seals DR. (1990). Endorphins and exercise: physiological mechanisms and clinical implications. Med Sci Sports Exercise; 22:417-428.

Vardar, SA., Öztürk, L., Vardar, E., Kurt, C. (2005). Ergen sporcu kızlarda egzersiz yoğunluğu ve öznel uyku kalitesi ilişkisi. Anadolu Psikiyatri Dergisi; 6:154-162.

Yakut, S. (2012). Lise öğrencilerinde dindarlık-şiddet eğilimi ilişkisi. Yayınlanmamış Yüksek Lisans Tezi, Süleyman Demirel Üniversitesi, Sosyal Bilimler Enstitüsü, Isparta.

Yavuzer, H. (2000). Çocuk ve Suç.: Remzi Kitabevi. İstanbul Üniversitesi, E.B.F.

Yavuzer, Y., Gündoğdu, R. ve Dikici, A. (2009).Teachers' perceptions about school violence in one Turkish city. Journal of School Violence, 8 (1): 29-41

Yeğen, B. (2008). Ortaöğretim öğrencilerinin sosyal uyumları ile saldırganlık düzeyleri arasındaki ilişkinin incelenmesi (Kadıköy ilçesi örneği). Yayımlanmamış yüksek lisans tezi, Yeditepe Üniversitesi, İstanbul. 